\title{
Cytopenias among ART-naive patients with advanced HIV disease on enrolment to care and treatment services at a tertiary hospital in Tanzania: A cross- sectional study
}

\author{
Daniel W. Gunda ${ }^{1}$, Kahamba G. Godfrey ${ }^{1}$, Semvua B. Kilonzo ${ }^{1}$, Bonaventura C. Mpondo ${ }^{2}$ \\ 1. Department of Internal Medicine, Weill Bugando School of Medicine, Mwanza, Tanzania \\ 2. Department of Internal Medicine, School of Health Sciences, University of Dodoma, Dodoma, Tanzania
}

Correspondence: Dr Daniel W. Gunda (daniel_rev2002@yahoo.com)

Background

Abstract

HIV/AIDS causes high morbidity and mortality through both immunosuppression and complications not directly related to immunosuppression. Haematological abnormalities, including various cytopenias, occur commonly in HIV through immune and non-immune pathways. Though these complications could potentially cause serious clinical implications, published literature on the magnitude of this problem and its associated factors in Tanzania is scarce. This study aimed at determining the prevalence and risk factors of HIV-associated cytopenias among ART-naive patients enrolling for care and treatment services at Bugando Care and Treatment Centre (CTC) in Mwanza, Tanzania.

Methods

This was a cross-sectional clinic-based study done between March 2015 and February 2016, involving all antiretroviral therapy (ART)-naive adult HIVpositive patients enrolling for care and treatment services at Bugando CTC. Patients younger than 18 years and those with missing data were excluded. Data were analysed using Stata version 11 to determine the prevalence and risk factors of cytopenias.

Results

A total of 1205 ART-naive patients were included. Median age was 41 years (interquartile range [IQR] 32 to 48). Most participants were female (n = 789; 65.6\%), with a female-to-male ratio of 2:1. The median baseline CD4 count was 200 cells/ $\mu \mathrm{L}$ (IQR 113 to 439 ). About half (49\%) of the study participants had baseline CD4 counts less than 200 cells/ $\mu \mathrm{L}$. Anaemia, leucopenia, and thrombocytopenia were found in $704(58.4 \%), 285$ (23.6\%), and $174(14.4 \%)$ participants, respectively, and these were strongly associated with advanced HIV infection.

Conclusions

The magnitude of cytopenias is high among ART-naive HIV-positive adults, and cytopenias are more marked with advanced HIV infection. Early diagnosis of HIV and timely initiation of ART could potentially reduce the number of people living with advanced HIV disease and its associated complications, including the cytopenias investigated in this study. Patients with cytopenias should undergo thorough screening for tuberculosis, which is an important and treatable correlate of cytopenia, in addition to close follow-up for any potential negative outcomes.

\section{Introduction}

HIV is still a global problem causing extensive morbidity and mortality worldwide, especially in sub-Saharan Africa, where more than $70 \%$ of all HIV cases occur. ${ }^{1}$ HIV-1 is the most virulent form of HIV and is responsible for most of the global burden of HIV disease. ${ }^{2}$

Morbidity and mortality in HIV/AIDS are mainly attributed to opportunistic infections and AIDS-defining illnesses. ${ }^{3} \mathrm{~A}$ considerable proportion of the ongoing efforts to reduce HIV/AIDS-related morbidity and mortality is devoted to scaling up access to HIV care and treatment services. ${ }^{4}$ In 2014, about 28 million people living with HIV/AIDS were eligible for antiviral therapy (ART); of these, about 15.8 million people were estimated to be receiving ART. ${ }^{1}$ The evidence accumulating on the effectiveness of ART suggests that the use of ART considerably improves survival of people living with HIV/AIDS by reducing the frequency of AIDS-related events. ${ }^{5,6}$

Despite these efforts and successeses, there is still a large burden of HIV-related morbidity and mortality, notably due to complications that are not secondary to immunosuppression. ${ }^{7,8}$ Haematological complications are reported to be among the most common nonimmunosuppressive complications of HIV. These frequently present as cytopenias, especially in ART-naive patients. These complications can have serious clinical consequences, including increased rate of AIDS progression and mortality from anaemia, as well as increased risk of bacterial infection $^{10}$ and bleeding ${ }^{11}$ from granulocytopenia and thrombocytopenia, respectively. However, published data on the magnitude of this problem and its associated factors are scarce in our setting. Therefore, the aim of this study was to determine the prevalence and risk factors of HIV-associated cytopenias among ART-naive adult HIV-positive patients enrolling for care and treatment services at Bugando Care and Treatment Centre in Mwanza, Tanzania.

\section{Methods}

\section{Study design, setting, and population}

This was a cross-sectional clinic-based study, carried out at Bugando Medical Centre (BMC), Care and Treatment Centre (CTC), between March 2015 and February 2016. BMC is a tertiary-level teaching hospital affiliated with the Catholic University of Health and Allied Sciences (CUHAS) and the Weill Bugando School of Medicine. It is located along the shores of Lake Victoria in Mwanza, Tanzania, and caters for the country's Lake and Western Zone. BMC has more than 900 beds and over 1000 employees. It currently serves a catchment population of around 16 million people from the Mwanza, Geita, Simiyu, Mara, Kagera, Shinyanga, Tabora, and Kigoma areas. It runs both teaching and treatment services, taking care of inpatients and outpatients. CTC activities are part of BMC's core and routine outpatient services. Currently, CTC serves more than 10,000 HIVpositive patients, either diagnosed within the centre or referred from one of the aforementioned catchment areas for expert management. 
Table 1: General demographic, clinical, and laboratory characteristics of 1205 ART-naive HIV-positive adults

\begin{tabular}{|c|c|c|c|}
\hline Characteristics & Frequency & Percentage & Median (IQR) \\
\hline \multicolumn{4}{|l|}{ Demographic variables } \\
\hline \multicolumn{4}{|l|}{ Age group (years) } \\
\hline$\geq 40$ Years & 611 & 50.7 & - \\
\hline$<40$ Years & 594 & 49.39 & - \\
\hline Median (IQR) age (years) & - & - & $41(32-48)$ \\
\hline \multicolumn{4}{|l|}{ Sex } \\
\hline Male & 416 & 34.4 & - \\
\hline Female & 789 & 65.6 & - \\
\hline \multicolumn{4}{|l|}{$\begin{array}{l}\text { WHO clinical stage of HIV } \\
\text { disease }\end{array}$} \\
\hline Stage $1 \& 2$ & 697 & 57.8 & - \\
\hline Stage $3 \& 4$ & 508 & 42.2 & - \\
\hline \multicolumn{4}{|l|}{ Baseline CD4 count $($ cells $/ \mu \mathrm{L})$} \\
\hline$<200$ & 594 & 49.3 & - \\
\hline 200 to 350 & 260 & 21.6 & - \\
\hline 351 to 500 & 97 & 8.1 & - \\
\hline$>500$ & 254 & 21.1 & - \\
\hline \multicolumn{4}{|l|}{$\begin{array}{l}\text { Median (IQR) laboratory } \\
\text { values }\end{array}$} \\
\hline CD 4 count $($ cells $/ \mu \mathrm{L})$ & - & - & $200(113-439)$ \\
\hline $\begin{array}{l}\text { Haemoglobin } \\
\text { concentration }(\mathrm{g} / \mathrm{dL})\end{array}$ & - & - & $11.3(9.5-13.0)$ \\
\hline $\begin{array}{l}\text { White blood cell count } \\
\left(\mathrm{x} 10^{9} / \mathrm{L}\right)\end{array}$ & - & - & $4.82(3.6-6.2)$ \\
\hline Platelet count $\left(\mathrm{x} 10^{9 / \mathrm{L}}\right)$ & - & - & $240(182-309)$ \\
\hline
\end{tabular}

$\mathrm{IQR}=$ interquartile range; $\mathrm{WHO}=$ World Health Organization

All adult ART-naive HIV-positive patients at Bugando CTC were eligible for this study. Patients younger than 18 years and those with missing lab result details were excluded. A minimum sample size of 384 was calculated from the prevalence studies' formula by Leslie and Kish, assuming a cytopenia prevalence of $50 \%$ among ART-naive HIVpositive adults. ${ }^{9} 12$ Consenting patients were sequentially enrolled until the sample size was reached. Pertinent patient data were recorded, including age, sex, opportunistic diseases present at the time of diagnosis, WHO clinical stage, baseline CD4 count, and most recent CD4 count. From the full blood count $(\mathrm{FBC})$ the following values were recored: absolute red blood cell count (RBC), white blood cell count (WBC), platelet count (Plt), haemgolobin level ( $\mathrm{Hb})$, and red blood cell indices.

\section{Blood sample collection and processing}

Five millilitres of whole blood was collected by venepuncture in Vacutainer tubes containing EDTA (Becton, Dickinson and Company, Franklin Lakes, NJ, USA) for FBC and CD4 count estimation. The samples were sent to BMC main laboratory within 2 hours for analysis. The FBC values were determined using a CELL-DYN 1800 (Abbott Laboratories, Diagnostics Division, Santa Clara, CA, USA) automated blood analyser, and the absolute CD4 counts were determined using the BD FACSCount system (Becton, Dickinson and Company, Franklin Lakes, NJ, USA).

\section{Statistical analysis}

Data were analysed using EpiData version 3.1 (The EpiData Association, Odense, Denmark) and Stata version 11 (StataCorp, College Station, TX, USA). In this study haematological abnormalities were defined according http://dx.doi.org/10.4314/mmj.v29i1.9 to World Health Organization (WHO) haematological reference ranges and as used in other studies. ${ }^{13-15}$ Anaemia was therefore defined as $\mathrm{Hb}<12.0$ for females and $\mathrm{Hb}<$ $13.0 \mathrm{~g} / \mathrm{dL}$ for male subjects. Leucopenia was defined as an absolute WBC $<3.5 \times 10^{9} / \mathrm{L}$, whereas thrombocytopenia was defined as an absolute Plt $<150 \times 10^{\circ} / \mathrm{L}$. The cytopenias were further classified by degree of severity as used in other studies. Based on this, $\mathrm{Hb}$ of 10.0 to $12.0 \mathrm{~g} / \mathrm{dL}$ (for females) or 10.0 to $13.0 \mathrm{~g} / \mathrm{dL}$ (for males) was considered mild anaemia, while moderate anaemia was defined as $\mathrm{Hb}$ between 8.0 and $10.0 \mathrm{~g} / \mathrm{dL}$ for both sexes, and $\mathrm{Hb}<8.0$ $\mathrm{g} / \mathrm{L}$ was considered severe anaemia. ${ }^{16,17}$ Mild, moderate, and severe thrombocytopenia were defined as Plt of 100 to 150 $\times 10^{9} / \mathrm{L}, 50$ to $100 \times 10^{9} / \mathrm{L}$, and $<50 \times 10^{9} / \mathrm{L}$, respectively. ${ }^{18}$ Mild, moderate, and severe leucopenia were defined as an absolute WBC of 3.0 to $3.5 \times 10^{9} / \mathrm{L}, 2.0$ to $3.0 \times 10^{9} / \mathrm{L}$, and $<2.0 \times 10^{9} / \mathrm{L}$, respectively. ${ }^{19}$ Advanced HIV was defined as CD 4 count $<200$ cells $/ \mu \mathrm{L}$ or presentation with a WHO stage 3 or 4 clinical event. ${ }^{20}$ Continuous variables were expressed as medians with interquartile ranges (IQRs) and categorical variables were expressed as proportions and percentages. The effect of different risk factors on the odds of having HIV-associated cytopenias was investigated. A univariate logistic regression model followed by a multivariate logistic regression model was used to calculate odds ratios (ORs) and $95 \%$ confidence intervals to quantify the strength of association between HIV-associated cytopenias and their potential predictors. In all of our analyses, factors were considered significantly associated with the outcome variable when the P-value was $\leq 0.05$.

\section{Ethical considerations}

Permission to conduct and publish the information from this study was obtained from the Joint CUHAS-BMC Research \& Ethics Committee. Written informed consent was obtained from all study participants. To maintain confidentiality, patient identifiers were not recorded. The results from this study will be of benefit for both teaching purposes and optimisation of patient care in our setting.

\section{Results}

\section{General demographic, clinical, and laboratory characteristics of study participants}

In this study, a total of 1205 ART-naive patients were included, with a median age of 41 years (IQR 32-48). Most participants were female $(\mathrm{n}=789 ; 65.6 \%)$, with a femaleto-male ratio of $2: 1$. The majority $(\mathrm{n}=697 ; 57.8 \%$ ) were classified as having WHO clinical stage 1 or 2 disease, and the median baseline CD4 count was 200 cells/ $\mu \mathrm{L}$ (IQR 113 to 439$)$. About half $(49 \%)$ of the study participants had baseline CD 4 counts were less than 200 cells/ $\mu \mathrm{L}$, and $21 \%$ had CD 4 counts above 500 cells $/ \mu \mathrm{L}$. The median baseline $\mathrm{Hb}$ was $11.3 \mathrm{~g} / \mathrm{dL}$ (IQR 9.5 to 13.0 ), whereas the median WBC and Plt values were $4.82 \times 10^{\circ} / \mathrm{L}$ (IQR 3.6 to 6.2 ) and $240 \times 10^{9} / \mathrm{L}$ (IQR 182 to 309 ), respectively (Table $1 \mathrm{a}$ ). Of the patients who presented with WHO clinical stage 1 or 2 HIV disease, most were diagnosed to have dermatological conditions, with pruritic papular eruption (PPE) being the most common diagnosis $(\mathrm{n}=348 ; 28.9 \%$ ), followed by herpetic eruptions $(\mathrm{n}=172 ; 14.3 \%)$. On the other hand, among those who presented with WHO clinical stage 3 or 4 disease, tuberculosis (TB) was the commonest diagnosis ( $\mathrm{n}$ $=425 ; 35.3 \%)$, followed by gastrointestinal candidiasis $(\mathrm{n}=$ 87; 7.2\%), as summarised in Figure 1. 


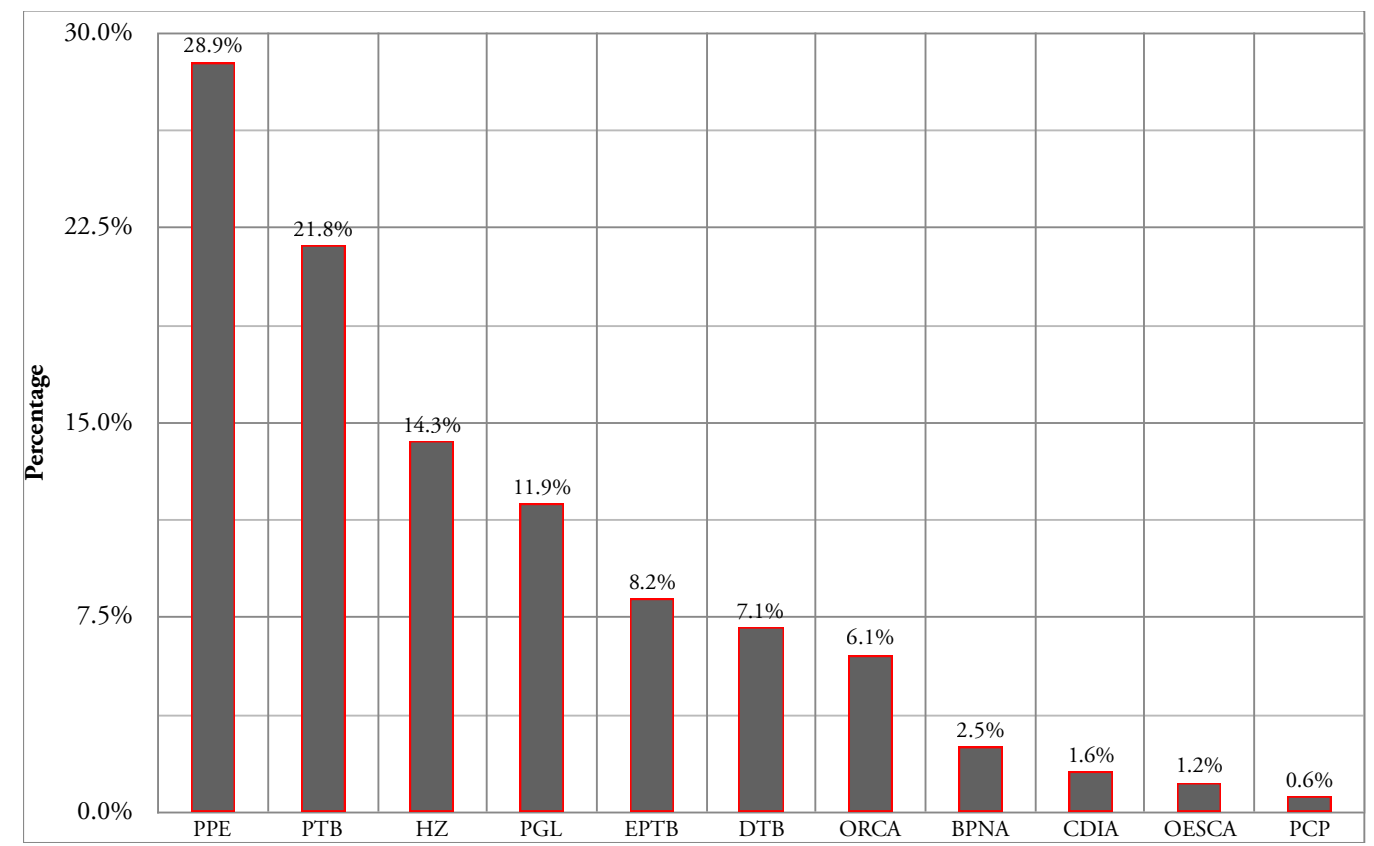

Figure 1: Opportunistic illness diagnoses among 1205 ART-naive HIV-positive adults

$\mathrm{PPE}=$ pruritic papular eruption; $\mathrm{PTB}=$ pulmonary tuberculosis; $\mathrm{HZ}=$ herpes zoster; $\mathrm{PGL}=$ persistent generalised lymphadenopathy; $\mathrm{EPTB}=$ extrapulmonary tuberculosis; $\mathrm{ORCA}=$ oral candidiasis; $\mathrm{BPNA}=$ recurrent bacterial pneumonia; $\mathrm{CDIA}=$ chronic diarrhoea; $\mathrm{OESCA}=$ oesophageal candidiasis; $\mathrm{PCP}=$ Pneumocystis jirovecii pneumonia

Table 2: Distribution of cytopenias by severity among 1205 ART-naive HIV-positive adults

\begin{tabular}{|c|c|c|c|}
\hline Severity level & Anaemia & Leucopenia & Thrombocytopenia \\
\hline \multicolumn{4}{|l|}{ Mild cytopenias } \\
\hline Range & $\begin{array}{c}\mathrm{Hb}\left(10.0 \text { to } 12.0^{\circ} \text { or }\right. \\
\left.13.0^{\circ} \mathrm{g} / \mathrm{dL}\right)\end{array}$ & WBC (3.0 to $\left.3.5 \times 10^{9} / \mathrm{L}\right)$ & Plt (100 to $\left.150 \times 10^{9 / L}\right)$ \\
\hline Frequency $(\%)$ & $352(29.2 \%)$ & $133(11.0 \%)$ & $134(11.1 \%)$ \\
\hline \multicolumn{4}{|l|}{ Moderate cytopenias } \\
\hline Range & $\mathrm{Hb}(8.0$ to $10.0 \mathrm{~g} / \mathrm{dL})$ & WBC $\left(2.0\right.$ to $\left.3.0 \times 10^{9} / \mathrm{L}\right)$ & Plt (50 to $100 \times 109 / \mathrm{L})$ \\
\hline Frequency $(\%)$ & $204(16.9)$ & $137(11.4 \%)$ & $24(2.0 \%)$ \\
\hline \multicolumn{4}{|l|}{ Severe cytopenias } \\
\hline Range & $\mathrm{Hb}(<8.0 \mathrm{~g} / \mathrm{dL})$ & WBC $\left(<2.0 \times 10^{9} / \mathrm{L}\right)$ & $\operatorname{Plt}\left(<50 \times 10^{9} / \mathrm{L}\right)$ \\
\hline Frequency (\%) & $148(12.2 \%)$ & $15(1.2 \%)$ & $16(1.3 \%)$ \\
\hline
\end{tabular}

$\mathrm{Hb}=$ haemoglobin concentration (note slightly different ranges used for females ${ }^{\circ}$ and males ${ }^{\widehat{\jmath}}$ ); $\mathrm{Plt}=$ platelet count; $\mathrm{WBC}=$ white blood cell count

The prevalence of cytopenias and their potential risk factors

A total of 704 (58.4\%) of the study participants were found to have anaemia, whereas leucopenia and thrombocytopenia were found in $285(23.7 \%)$ and $174(14.4 \%)$ of the participants, respectively. Bicytopenia occurred in at least $88(7.30 \%)$ of the participants, with anaemia and leucopenia being the most common combination $(\mathrm{n}=193 ; 16.0 \%)$. Pancytopenia occurred in $61(5.1 \%)$ of the studied patients (Figure 2). By severity, $148(12.2 \%)$ of the study participants had severe anaemia, whereas severe leucopenia and thrombocytopenia were observed in $15(1.2 \%)$ and $16(1.3 \%)$ of the studied patients, respectively (Table 2). Anaemia commonly occurred among patients with WHO clinical stage 3 and 4 disease (48.3\% and $33.5 \%, \mathrm{P}<0.001$ ), and among those with baseline CD4 counts less than 200 cells $/ \mu \mathrm{L}(\mathrm{OR}=1.3, \mathrm{P}<0.020)$. While tuberculosis was the commonest opportunistic condition, the odds of having anaemia were significantly associated with a pulmonary tuberculosis $(\mathrm{PTB})$ diagnosis $(\mathrm{OR}=1.5$, $\mathrm{P}=0.01)$ and disseminated tuberculosis $(\mathrm{DTB})(\mathrm{OR}=2.7$,
$\mathrm{P}<0.001)$. Using a multivariate regression model, anaemia was independently associated with WHO clinical stage 3 or $4 \mathrm{HIV}$ disease $(\mathrm{OR}=1.5, \mathrm{P}=0.016), \mathrm{CD} 4$ counts $<200$ cells $/ \mu \mathrm{L}(\mathrm{OR}=1.3, \mathrm{P}=0.04)$, and $\mathrm{DTB}(\mathrm{OR}=2.1, \mathrm{P}=$ 0.019), as summarised in Table 3.

Table 4 shows that leucopenia was strongly predicted by a female gender $(\mathrm{OR}=1.5, \mathrm{P}=0.006)$ in addition to HIV WHO clinical stage 3 or 4 (OR $=1.8, \mathrm{P}<0.001)$, PTB (OR $=1.5, \mathrm{P}=0.016), \mathrm{DTB}(\mathrm{OR}=2.0, \mathrm{P}=0.003)$ and baseline CD4 of less than 200 cells $/ \mu \mathrm{L}(\mathrm{OR}=2.8, \mathrm{P}<0.001)$. Using a multivariate model (see Table 4), leucopenia was independently associated with a female gender $(\mathrm{OR}=1.5$, $\mathrm{P}=0.009), \mathrm{CD} 4$ count less than $200 / \mu \mathrm{L}(\mathrm{OR}=2.8, \mathrm{P}<$ $0.001)$, and $\mathrm{DTB}(\mathrm{OR}=1.8, \mathrm{P}=0.04)$.

Thrombocytopenia was strongly predicted also by WHO clinical stage 3 or 4 disease $(\mathrm{OR}=1.9, \mathrm{P}<0.001)$, baseline CD4 less than 200 cells $/ \mu \mathrm{L}(\mathrm{OR}=1.6, \mathrm{P}=0.003)$, and DTB $(\mathrm{OR}=2.5, \mathrm{P}<0.001)$; all of these factors remained as independent risk factors for thrombocytopenia on a multivariate model, as summarised in Table 5. 
Table 3: Univariate and multivariate analysis for factors associated with anaemia among 1205 ART-naive HIV-positive adults

\begin{tabular}{|c|c|c|c|c|c|c|}
\hline \multirow[t]{2}{*}{ Variable } & \multicolumn{2}{|c|}{$\begin{array}{c}\text { Anaemia } \\
\left(\mathrm{Hb}<12.0^{\circ} \text { or } 13.0^{\circ} \mathrm{g} / \mathrm{dL}\right)\end{array}$} & \multirow{2}{*}{$\begin{array}{l}\text { Unadjusted } \\
\text { OR }(95 \% \mathrm{CI})\end{array}$} & \multirow[t]{2}{*}{ P-value } & \multirow{2}{*}{$\begin{array}{c}\text { Adjusted } \\
\text { OR }(95 \% \mathrm{CI})\end{array}$} & \multirow[t]{2}{*}{ P-value } \\
\hline & No (\%) & Yes (\%) & & & & \\
\hline \multicolumn{7}{|l|}{ Age group } \\
\hline$\geq 40$ years & $247(49.3)$ & $364(51.7)$ & - & - & - & - \\
\hline$<40$ years & $254(50.7)$ & $340(48.3)$ & $1.1(0.9$ to 1.4$)$ & 0.41 & - & - \\
\hline \multicolumn{7}{|l|}{ Sex } \\
\hline Female & $334(66.7)$ & $455(64.6)$ & - & - & - & - \\
\hline Male & $167(33.3)$ & $249(35.4)$ & $0.9(0.7$ to 1.2$)$ & 0.46 & - & - \\
\hline \multicolumn{7}{|l|}{ WHO clinical HIV stage } \\
\hline Stage $1 \& 2$ & $333(66.5)$ & $364(51.7)$ & $1.9(1.5$ to 2.3$)$ & $<0.001$ & $1.5(1.1$ to 2.2$)$ & 0.016 \\
\hline Stage $3 \& 4$ & $168(33.5)$ & $340(48.3)$ & - & - & - & - \\
\hline \multicolumn{7}{|l|}{$\begin{array}{l}\text { Baseline CD4 count } \\
(\text { cells } / \mu \mathrm{L})\end{array}$} \\
\hline$<200$ & $227(45.3)$ & $367(52.2)$ & - & - & - & - \\
\hline$\geq 200$ & $274(54.7)$ & $337(47.8)$ & $1.3(1.0$ to 1.7$)$ & 0.020 & $1.3(1.0$ to 1.6$)$ & 0.040 \\
\hline \multicolumn{7}{|l|}{$\begin{array}{l}\text { Opportunistic disease } \\
\text { diagnosis }\end{array}$} \\
\hline $\begin{array}{l}\text { Pruritic papular } \\
\text { eruptions }\end{array}$ & $158(31.5)$ & $190(27.0)$ & $0.8(0.6$ to 1.0$)$ & 0.10 & - & - \\
\hline $\begin{array}{l}\text { Pulmonary } \\
\text { tuberculosis }\end{array}$ & $914(18.2)$ & $172(24.4)$ & $1.5(1.1$ to 1.9$)$ & 0.010 & $1.1(0.7$ to 1.7$)$ & 0.60 \\
\hline Herpes zoster & $82(16.4)$ & $90(12.8)$ & $0.7(0.5$ to 1.0$)$ & 0.080 & - & - \\
\hline $\begin{array}{l}\text { Persistent generalised } \\
\text { lymphadenopathy }\end{array}$ & $71(14.2)$ & $74(10.5)$ & $0.7(0.5$ to 1.0$)$ & 0.055 & - & - \\
\hline $\begin{array}{l}\text { Extrapulmonary } \\
\text { tuberculosis }\end{array}$ & $33(06.6)$ & $66(09.4)$ & $1.5(0.9$ to 2.3$)$ & 0.084 & - & - \\
\hline $\begin{array}{l}\text { Disseminated } \\
\text { tuberculosis }\end{array}$ & $19(03.8)$ & $67(09.5)$ & $2.7(1.6$ to 4.5$)$ & $<0.001$ & $2.1(1.1$ to 3.7$)$ & 0.019 \\
\hline Oral candidiasis & $29(05.8)$ & $44(06.3)$ & $1.1(0.7$ to 1.8$)$ & 0.33 & - & - \\
\hline Bacterial pneumonia & $8(01.6)$ & $22(03.1)$ & $2.0(0.9$ to 4.5$)$ & 0.099 & - & - \\
\hline
\end{tabular}

$\mathrm{Hb}=$ haemoglobin concentration; ${ }^{\circ}=$ female; ${ }^{\hat{~}}=$ male; $\mathrm{OR}=$ odds ratio; $\mathrm{CI}=$ confidence interval; $\mathrm{WHO}=$ World Health Organization

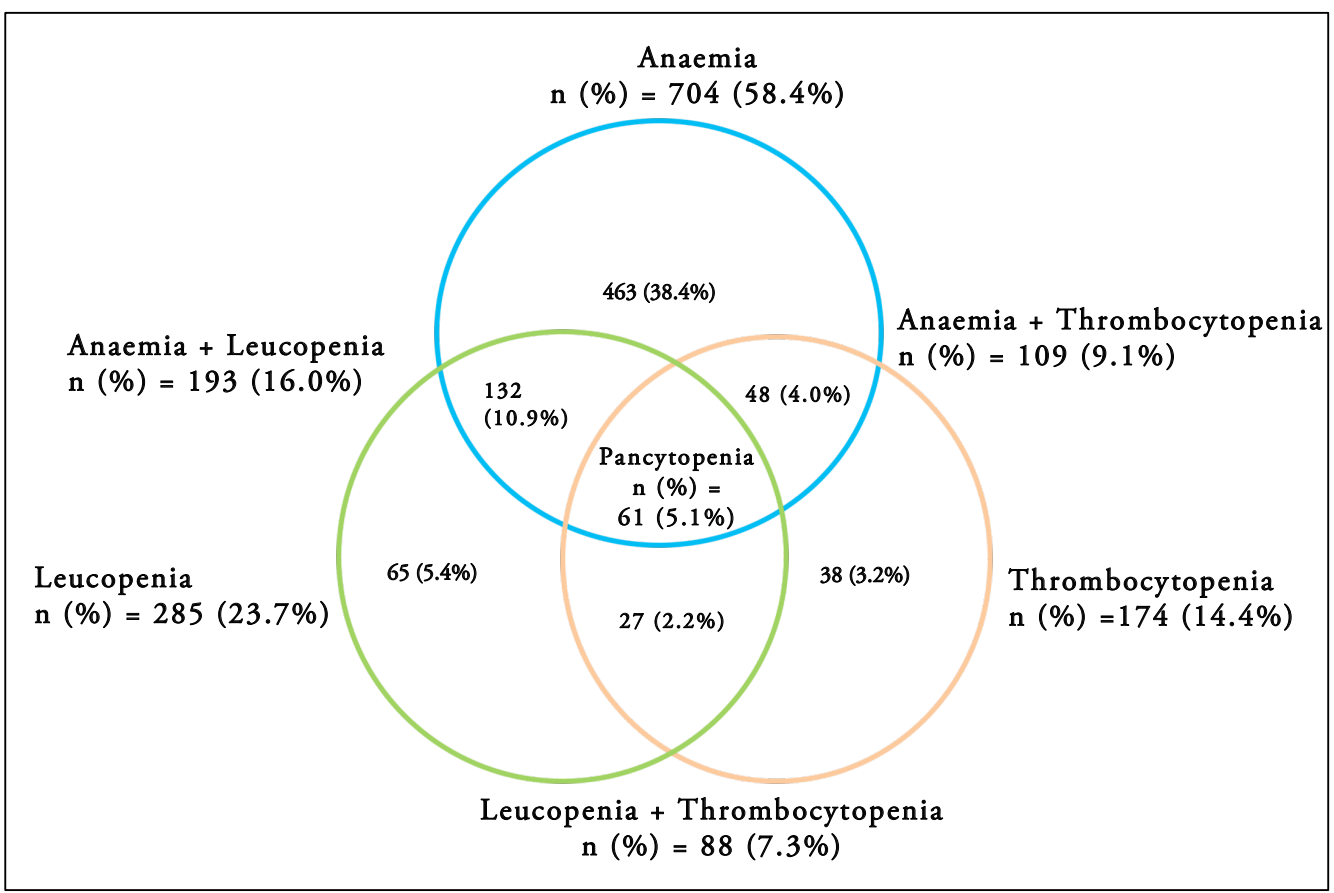

Figure 2: Distribution of cytopenias among 1205 ART-naive HIV-positive adults 
Table 6 summarises the univariate and multivariate analyses for factors associated with multiple cytopenias. Patients who had multiple cytopenias were likely to be female $(\mathrm{OR}=1.4$, $\mathrm{P}=0.05)$, in WHO clinical stage 3 or $4(\mathrm{OR}=2.1, \mathrm{P}<$ 0.001), with baseline CD4 counts less than 200 cells/ $\mu \mathrm{L}(\mathrm{OR}=3.2, \mathrm{P}<0.001)$, and those diagnosed to have PTB $(\mathrm{OR}=1.5, \mathrm{P}=0.015)$, DTB $(\mathrm{OR}=2.5, \mathrm{P}<0.001)$, and recurrent bacterial pneumonia $(\mathrm{OR}=2.3, \mathrm{P}$ $=0.04)$. On a multivariate logistic regression model, multiple cytopenias remained independently predicted by CD4 counts less than 200 cells $/ \mu \mathrm{L}(\mathrm{OR}=3.1, \mathrm{P}<$ $0.001)$, and DTB (OR $=2.5$, $\mathrm{P}=0.012)$. The strength of association of other factors with multiple cytopenias was not statistically significant.

\section{Discussion}

The objective of this study was to determine the prevalence and risk factors of HIV-associated cytopenias. Anaemia was found to be the most frequent HIV-associated cytopenia, occurring in $704(58.4 \%)$ of the study participants, followed by leucopenia and thrombocytopenia, which were found in $285(23.7 \%)$ and $174(14.4 \%)$ of the participants, respectively. In previous studies, anaemia has been reported in more than $60 \%$ of patients. ${ }^{9,14}$ Compared to our study, lower anaemia prevalences have been reported in India $(22 \%),{ }^{21}$ Ethiopia (35\%), ${ }^{22}$ Uganda $(47.8 \%),{ }^{23}$ and Nigeria $(57.5 \%) .{ }^{24}$ On the other hand, our study reports a lower anaemia prevalance than several other studies that investigated anaemia prevalence among ART-naive patients. In a study from India, by Byomakesh et al., anaemia was found in $65.5 \%$ of the study participants, ${ }^{14}$ while a prior study in rural Tanzania by Johannessen et al. in 2011 reported a prevalence of $77.4 \%$ among ART-naive HIV-positive adults. ${ }^{25}$ Daka et al. reported an anaemia prevalence of $86.5 \%$ among ART-naive HIV positive patients in Ethiopia. ${ }^{26}$

Among a number of studies that have reported on HIVassociated cytopenias involving other cell lines, results have been consistently comparable to our findings. Leucopenia is also common in ART-naive patients, with a prevalence that ranges between $10 \%$ and $44 \% .{ }^{12,27}$ A study from northern Ethiopia indicated that $16.6 \%$ of ART-naive patients had leucopenia, while $9.0 \%$ had thrombocytopenia. ${ }^{28}$ In Uganda, leucopenia and thrombocytopenia were reported in $24.3 \%$ and $8.3 \%$ of the study participants, respectively. ${ }^{23}$ Akinsegun et al., in a 2010 study, reported leucopenia and thrombocytopenia in $26.8 \%$ and $16.1 \%$ of ART-naive patients, respectively, in a Nigerian population. ${ }^{29}$ Earlier studies indicated that platelet counts of less than 150 were more common among ART-naive patients, with prevalence figures ranging between $6 \%$ and $30 \%$ in most studies. ${ }^{12,27,30}$

Evidence from available studies has shown that patients with anaemia have reduced survival time and accelerated HIV disease progression. For instance, an earlier study in developed countries by Mocroft et al. indicated that, at 12 months, HIV patients with mild anaemia had a significantly lower survival rate than those without anaemia $(84.1 \%$ vs. $96.9 \%$, and that prognosis and survival time was even worse among severely anemic patients. ${ }^{31}$ Similarly, in the USA, Sullivan and colleagues found that survival rate was considerably reduced among anaemic HIV patients, with a relative risk of death of $148 \%{ }^{8}$ Another study in Tanzania by O'Brien et al. showed that anaemia is an independent risk factor for mortality and disease progression among HIVpositive women. ${ }^{32}$ In this study patients with anaemia had increased risk of mortality, with a hazard ratio (HR) of 2.06 for mild anaemia, 2.7 for moderate anaemia, and 3.19 for severe anaemia.

Despite the high frequency of cytopenias in other cell lines, clinical implications and specific treatments are not well described. Available studies from developed countries 
Table 5: Univariate and multivariate analysis for factors associated with thrombocytopenia among 1205 ART-naive HIV-positive adults

\begin{tabular}{|c|c|c|c|c|c|c|}
\hline \multirow{2}{*}{ Variable } & \multicolumn{2}{|c|}{$\begin{array}{c}\text { Thrombocytopenia } \\
(\text { Plt }<1.5 \times 10 \% / L)\end{array}$} & \multirow{2}{*}{$\begin{array}{c}\text { Unadjusted } \\
\text { OR }(95 \% \mathrm{CI})\end{array}$} & \multirow{2}{*}{ P-value } & \multirow{2}{*}{$\begin{array}{c}\text { Adjusted } \\
\text { OR }(95 \% \text { CI })\end{array}$} & \multirow{2}{*}{ P-value } \\
\hline & No $(\%)$ & Yes (\%) & & & & \\
\hline \multicolumn{7}{|l|}{ Age group } \\
\hline$\geq 40$ years & $530(51.4)$ & $081(46.6)$ & - & - & - & - \\
\hline$<40$ years & $501(48.6)$ & $093(53.4)$ & $0.8(0.6$ to 1.1$)$ & 0.24 & - & - \\
\hline \multicolumn{7}{|l|}{ Sex } \\
\hline Female & $672(65.2)$ & $117(67.2)$ & - & - & - & - \\
\hline Male & $359(34.8)$ & $57(32.8)$ & $1.1(0.8$ to 1.5$)$ & 0.60 & - & - \\
\hline \multicolumn{7}{|l|}{ WHO clinical HIV stage } \\
\hline Stage $1 \& 2$ & $619(60.1)$ & $78(44.8)$ & $1.9(1.3$ to 2.6$)$ & $<0.001$ & $1.6(1.1$ to 2.2$)$ & 0.010 \\
\hline Stage $3 \& 4$ & $412(39.9)$ & $96(55.2)$ & - & - & - & - \\
\hline \multicolumn{7}{|l|}{$\begin{array}{l}\text { Baseline CD4 count } \\
(\text { cells/ } \mu \mathrm{L})\end{array}$} \\
\hline$<200$ & $490(47.5)$ & $104(59.8)$ & - & - & - & - \\
\hline$\geq 200$ & $541(52.5)$ & $70(40.2)$ & $1.6(1.2$ to 2.3$)$ & 0.003 & $1.6(1.1$ to 2.2$)$ & 0.008 \\
\hline \multicolumn{7}{|l|}{$\begin{array}{l}\text { Opportunistic disease } \\
\text { diagnosis }\end{array}$} \\
\hline $\begin{array}{l}\text { Pruritic papular } \\
\text { eruptions }\end{array}$ & $313(30.4)$ & $34(19.5)$ & $0.6(0.4-0.8)$ & 0.004 & - & - \\
\hline $\begin{array}{l}\text { Pulmonary } \\
\text { tuberculosis }\end{array}$ & $216(21.0)$ & $47(27.0)$ & $1.4(1.0$ to 2.0$)$ & 0.074 & - & - \\
\hline Herpes zoster & $151(14.7)$ & $21(12.1)$ & $0.8(0.5$ to 1.3$)$ & 0.37 & - & - \\
\hline $\begin{array}{l}\text { Persistent generalised } \\
\text { lymphadenopathy }\end{array}$ & $126(12.2)$ & $19(10.9)$ & $0.9(0.5$ to 1.5$)$ & 0.63 & - & - \\
\hline $\begin{array}{l}\text { Extrapulmonary } \\
\text { tuberculosis }\end{array}$ & $94(9.1)$ & $5(2.9)$ & $0.3(0.1$ to 0.7$)$ & 0.009 & - & - \\
\hline $\begin{array}{l}\text { Disseminated } \\
\text { tuberculosis }\end{array}$ & $62\left(\begin{array}{ll}0 & 6.0\end{array}\right)$ & $24(13.8)$ & $2.5(1.5$ to 4.1$)$ & $<0.001$ & $1.9(1.1$ to 3.2$)$ & 0.022 \\
\hline Oral candidiasis & $59(05.7)$ & $14(8.1)$ & $1.4(0.8$ to 2.6$)$ & 0.24 & - & - \\
\hline Bacterial pneumonia & $22(2.1) 3$ & $8(4.6)$ & $2.2(1.0$ to 5.0$)$ & 0.060 & - & - \\
\hline
\end{tabular}

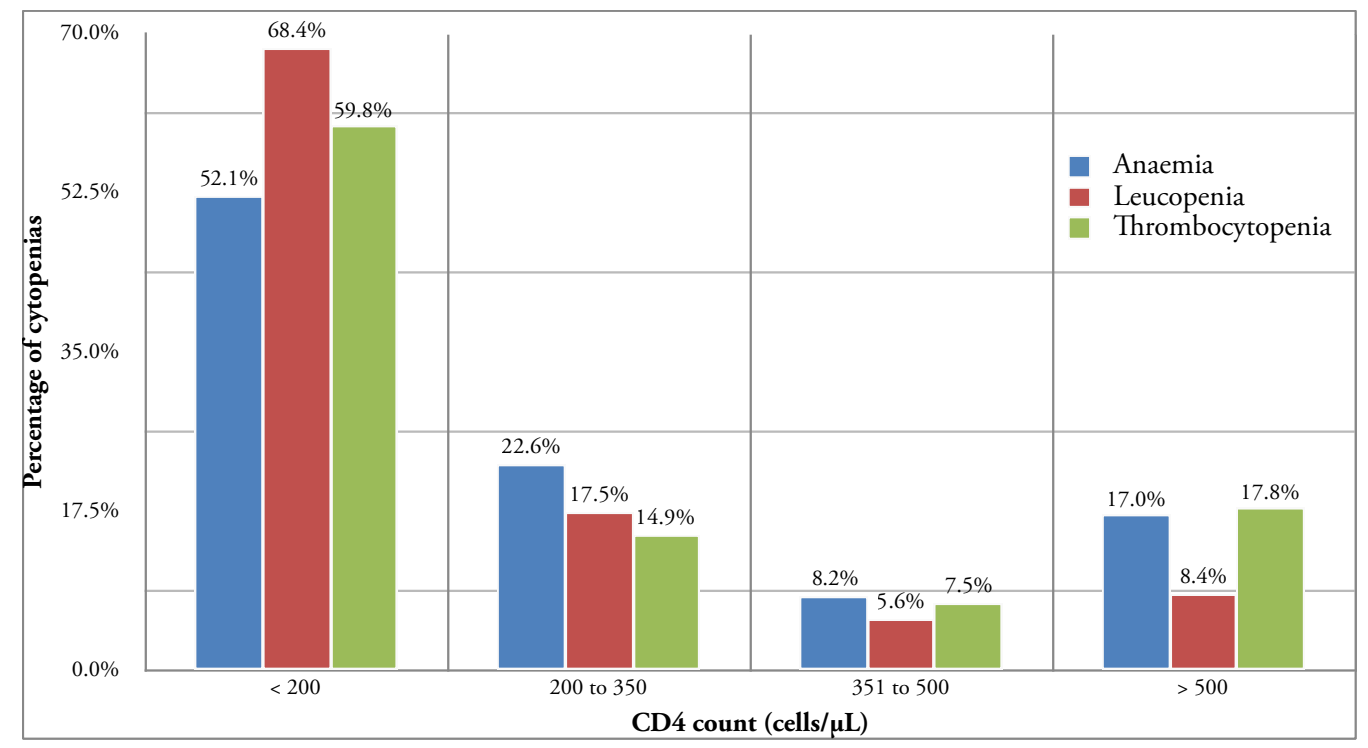

Figure 3: Cytopenia type by CD4 count among 1205 ART-naive HIV-positive patients 
indicate that a reduction in absolute white blood cell count has been associated with increased risk of severe bacterial infection and hospitalisation, ${ }^{10}$ and that patients with thrombocytopenia have a high potential for bleeding. ${ }^{11}$ However, with a lack of comparable studies from Africa, these findings are difficult to generalise to the African region. Initiation of ART has generally been regarded as the standard management for HIV/ AIDS patients. In addition to the restoration of immunological function, ART has also been shown to improve HIVrelated cytopenias, especially anaemia. $^{25,33,34}$ A study by Johannessen et al. recorded a reduction of anaemia from $77.4 \%$ among ART-naive patients to $38.2 \%$ after 12 months of ART. ${ }^{25}$ A study in Nigeria demonstrated a reduction in anaemia prevalence from $69.17 \%$ to $51.15 \%$ after ART.35 Another study in Nigeria, by Denue et al., also showed a significant improvement of haematological parameters with ART: the prevalence of

Table 6: Univariate and multivariate analysis for factors associated with multiple cytopenias among 1205 ART-naive HIV-positive adults

\begin{tabular}{|c|c|c|c|c|c|c|}
\hline \multirow{2}{*}{ Variable } & \multicolumn{2}{|c|}{ Multicytopenia } & \multirow{2}{*}{$\begin{array}{c}\text { Unadjusted } \\
\text { OR }(95 \% \mathrm{CI})\end{array}$} & \multirow{2}{*}{ P-value } & \multirow{2}{*}{$\begin{array}{c}\text { Adjusted } \\
\text { OR }(95 \% \text { CI })\end{array}$} & \multirow{2}{*}{ P-value } \\
\hline & No $(\%)$ & Yes $(\%)$ & & & & \\
\hline
\end{tabular}

Age group

\section{$\geq 40$ years}

$<40$ years

505 (49.9)

$104(53.9)$

Sex

Female

Male

\section{WHO clinical HIV stage}

Stage $1 \& 2$

Stage $3 \& 4$

Baseline CD4 count

$($ cells $/ \mu \mathrm{L})$

$$
<200
$$$$
\geq 200
$$

$557(55.0)$

$139(72.0)$

Opportunistic disease

diagnosis

\begin{tabular}{|c|c|c|c|c|c|c|}
\hline $\begin{array}{l}\text { Pruritic papular } \\
\text { eruptions }\end{array}$ & $299(29.6)$ & $48(24.9)$ & $0.8(0.6$ to 1.1$)$ & 0.19 & - & - \\
\hline $\begin{array}{l}\text { Pulmonary } \\
\text { tuberculosis }\end{array}$ & $208(20.6)$ & $55(28.5)$ & $1.5(1.1$ to 2.2$)$ & 0.015 & $1.4(0.8$ to 2.4$)$ & 0.19 \\
\hline Herpes zoster & $157(15.5)$ & $15(7.8)$ & $0.5(0.3$ to 0.8$)$ & 0.006 & - & - \\
\hline $\begin{array}{l}\text { Persistent generalised } \\
\text { lymphadenopathy }\end{array}$ & $125(12.4)$ & $20(10.4)$ & $0.8(0.5$ to 1.4$)$ & 0.44 & - & - \\
\hline $\begin{array}{l}\text { Extrapulmonary } \\
\text { tuberculosis }\end{array}$ & $86(8.5)$ & $13(6.7)$ & $0.8(0.4$ to 1.4$)$ & 0.42 & - & - \\
\hline $\begin{array}{l}\text { Disseminated } \\
\text { tuberculosis }\end{array}$ & $60(5.9)$ & $26(13.5)$ & $2.5(1.5$ to 4.0$)$ & $<0.001$ & $2.3(1.2$ to 4.3$)$ & 0.012 \\
\hline Oral candidiasis & $58(05.7)$ & $15(07.8)$ & $1.4(0.8$ to 2.5$)$ & 0.28 & - & - \\
\hline Bacterial pneumonia & $21(02.1)$ & $9(4.7)$ & $2.3(1.0$ to 5.1$)$ & 0.040 & $2.1(0.8$ to 5.0$)$ & 0.11 \\
\hline
\end{tabular}

anaemia was reduced from $57.5 \%$ pre-ART to $24.3 \%$ postART, while leucopenia and thrombocytopenia were reduced from $6.1 \%$ and $9.6 \%$ to $1.7 \%$ and $1.2 \%$, respectively. ${ }^{24}$ An important observation from available studies is that even with this great effect of AR'T on HIV-associated cytopenias, the reversal of these complications is usually incomplete. This suggests that the mechanisms underlying HIVassociated cytopenias are complex and can only be reversed partially with the use of ART. Among other mechanisms, studies suggest reduced marrow activity in the production of different cell lines, which can be due to HIV itself, opportunistic infections, or cytokine-mediated changes, ${ }^{36,37}$ with a tendency for the effects of these mechanisms to increase in magnitude with worsening HIV disease. For example, regarding anaemia, studies illustrate that among asymptomatic HIV-positive patients, anaemia occurs in $8 \%$ to $18 \%$ of patients, as compared to $20 \%$ to $50 \%$ of patients with intermediate disease progression, and $70 \%$ to $75 \%$ of patients with advanced HIV. ${ }^{38,39}$ In an Ethiopian study, where $29.7 \%, 16.6 \%$, and $9 \%$ of ART-naive patients had anaemia, leucopenia, and thrombocytopenia, respectively, it was indicated that at CD4 counts greater than 350 cells/ $\mu \mathrm{L}$, only $18.8 \%, 15.3 \%$, and $3.5 \%$ of these patients had anaemia, leucopenia, and thrombocytopenia respectively. Comparatively, at CD 4 counts less than 200 cells/ $\mu \mathrm{L}$, it was indicated that there was a much higher rate of cytopenias with anaemia, leucopenia, and thrombocytopenia being http://dx.doi.org/10.4314/mmj.v29i1.9 reported in $34.5 \%, 43.1 \%$, and $15.5 \%$ of the ART-naive patients with cytopenias. ${ }^{28}$ Another study in Nigeria by Akinsegun et al., studying haematological abnormalities in ART-naive patients, demonstrated that at CD4 counts above 500 cells $/ \mu \mathrm{L}$, anaemia occurred in only $5.26 \%$ of the study participants, while leucopenia and thrombocytopenia were found in $10.5 \%$ and $13.15 \%$ of the study participants, respectively. Conversely, at a CD4 count of less than 200 cells $/ \mu \mathrm{L}$, anaemia was present in between $50 \%$ and $71 \%$ of study participants, whereas leucopenia occurred in $55 \%$ to $75 \%$ of participants, and thrombocytopenia in $15 \%$ to $53.3 \%{ }^{29}$ These observations are also supported by our finding that among those patients with anaemia, 8.2\%, 22.6\%, and $52.1 \%$ had mild, moderate, and severe immunosuppression. Additionally, in the current study it was noted that at CD4 counts above 500 cells $/ \mu \mathrm{L}$, only $17.0 \%, 8.4 \%$, and $17.8 \%$ of patients had anaemia, leucopenia, and thrombocytopenia, respectively, compared to $52.1 \%, 68.4 \%$, and $59.8 \%$ at CD4 counts less than 200 cells $/ \mu \mathrm{L}$ (Figure 3).

In our study, patients with WHO clinical stage 3 or 4 disease were 1.8 times more likely to have anaemia and leucocytopenia and 1.9 times more likely to have thrombocytopenia. Additionally they were 2.1 and 2.7 times more likely to have bicytopenia and pancytopenia than patients with WHO clinical stage 1 or 2 disease. Patients with baseline CD4 counts less than 200 cells $/ \mu \mathrm{L}$ were 1.4 to 2.8 times more likely to have anaemia, thrombocytopenia, and leucopenia.

MMJ VOL 29 (1): March 2017 
HIV-associated cytopenias represent an ongoing challenge because of the variety of potential aetiologies, which are in most cases difficult to adequately investigate and treat. For example, anaemia is the commonest form of HIV-associated cytopenia and has frequently been associated with several factors that may either cause reduced bone marrow activity, chronic blood loss, or peripheral red blood cell destruction. ${ }^{40}$ Reduced bone marrow activity frequently follows (1) marrow infiltrative diseases like opportunistic infections and malignances, ${ }^{41}$ (2) inadequate marrow stimulation (for example, from reduced erythropoietin production), ${ }^{42}$ (3) bone marrow suppression (from medications like zidovudine $[\mathrm{AZT}]$ and cotrimoxazole [CTX] or from the suppressive effects of soluble proteins from HIV and cytokines), ${ }^{43,44}$ (4) nutritional deficiencies with reduced raw material supply (iron, folate, and vitamin B12), ${ }^{45,46}$ among others. In HIV patients, chronic blood loss is a potential cause of anaemiacommonly from gastrointestinal lesions like Kaposi's sarcoma, oral and oesophageal candidiasis, cytomegalovirus, oesophagitis, or colitis, and from hookworm infestations. ${ }^{40}$ Haemolytic anaemia in HIV-positive patients usually follows autoimmune reaction (autoimmune haemolytic anaemia, AIHA), and though less frequent, patients with AIHA may potentially react to blood transfusion when this cause of anaemia is not ruled out. ${ }^{47}$

Thrombocytopenia in HIV patients has been shown to be a frequent complication among cirrhotic patients with associated portal hypertension, where it occurs in more than $50 \%$ of this subgroup of patients. ${ }^{48,49}$ Reduced production of thrombopoetin, splenic sequestration, and platelet autoantibodies developing following hepatitis C infection, among others, form a list of possible mechanisms for thrombocytopenia among cirrhotic patients. ${ }^{50,51}$ A number of drugs have also been implicated to cause drug-induced thrombocytopenia (DITP), including trimethoprim, quinine, nonsteroidal antiinflammatory drugs (NSAIDs), and anticonvulsants. $^{52,53}$ Furthermore, thrombocytopenia has been reported in more than $30 \%$ of patients with sepsis. In these patients, thrombocytopenia is usually associated with disseminated intravascular coagulation (DIC), with increased platelet destruction. ${ }^{54}$ The thrombocytopenia in sepsis results partly from an associated nonimmune platelet destruction and bone marrow suppression with severity of thrombocytopenia correlating closely to severity of sepsis. ${ }^{55}$ HIV-associated thrombotic thrombocytopenic purpura (TTP) is an important cause of thrombocytopenia, first described in $1987 .{ }^{56} \mathrm{HIV}$ is presumed to precipitate TTP through direct endothelial damage, which in turn causes local generation of thrombin and consumption of metaloprotease, ${ }^{57}$ and it commonly occurs in patients with advanced HIV disease. ${ }^{58}$ TTP is usually characterised by microvascular platelet deposition and thrombus formation in selected organs with eventually thrombocytopenia, fever and haemolytic anaemia, neurological and renal dysfunction, among others. ${ }^{59}$

In HIV patients, the causes of leucopenia include (1) reduced bone marrow activity from infiltrative conditions, marrow toxicity, and nutritional deficiency; (2) increased apoptosis; (3) HIV infection itself; (4) tuberculous marrow infiltrate; and (5) neoplastic infiltrates. ${ }^{60-62}$ On the other hand, most drugs which are currently useful in HIV, such as CTX, AZT, and gancyclovir are myelotoxic, ${ }^{63}$ and they can potentially cause neutropenia. HIV antibodies against gp120 form another mechanism which leads to suppression of marrow progenitors. ${ }^{64}$ Leucopenia could also follow nutritional http://dx.doi.org/10.4314/mmj.v29i1.9 deficiency of Vitamin B12,62 and a shortened neutrophil lifespan from accelerated apoptosis in HIV. ${ }^{65}$

With regards to opportunistic diseases present at the time of diagnosis in our study, TB was the most common diagnosis, and it was strongly associated with all forms of cytopenia, especially the disseminated form of $\mathrm{TB}$, which was as an independent risk factor for cytopenias. This supports the understanding that TB is one of the marrow infiltrative diseases that can potentially lead to reduced production of all cell lines. These findings are in agreement with several other studies. A prior study from Muhimbili had shown that patients with anaemia were 3 times more likely to have TB than patients without anaemia. ${ }^{66}$ Studies from elsewhere have also indicated that the prevalence of TB among anaemic HIV patients is high especially among patients with severe anaemia. A study from South Africa by Kerkhoff et al., assessing the prevalence of TB among HIV anaemic patients, indicated that TB was diagnosed in only $8.8 \%$ of non-anemic HIV patients, compared to $16.5 \%, 26.0 \%$, and $40.0 \%$ among those with mild, moderate, and severe anaemia, respectively. ${ }^{67}$ In an earlier study from the USA studying 76 bone marrow samples among patients with cytopenias, 55 samples $(72 \%)$ were positive for TB. ${ }^{68}$ Additionally, a study from India indicated that TB was a common bone marrow infection among patients with anaemia, leucopenia, and thrombocytopenia ${ }^{69}$ These findings are clinically important, especially in resource-limited settings where HIV and TB burden are highest, such that TB represents an important reversible cause of cytopenia and should routinely be suspected among HIV patients presenting with cytopenia.

\section{Study limitations}

This study had a number of limitations. This was a single centre, and it was a hospital-based study, therefore the findings may not necessarily be generalisable. Since this was a cross-sectional study, there was no follow up, and hence a longitudinal study is recommended to answer questions related to outcomes.

\section{Conclusions}

HIV-associated cytopenias are common and tend to increase in magnitude and severity with worsening HIV disease. These findings also suggest that efforts to diagnose HIV at earlier stages might serve as an important strategy in the reduction of most cytopenias in this subgroup of patients. Earlier diagnosis may lead to earlier ART initiation and improved outcomes. Furthermore, patients with advanced HIV should be given special attention, as they are more likely to be affected by cytopenias, which may only partially resolve with ART. Tuberculosis, in particular, should be ruled out often, as it is a treatable cause of the cytopenias commonly seen in HIV-positive patients.

\section{Competing interests}

The authors declare that they have no conflicts of interest.

\section{References}

\section{WHO, HIV/AIDS-Fact sheet. 2015.}

2. Marlink, R., et al., Reduced rate of disease development after HIV-2 infection as compared to HIV-1. Science, 1994. 265(5178): p. 1587-90.

3. Brooks, J.T., et al., HIV-associated opportunistic infections--going, going, but not gone: the continued need for prevention and treatment guidelines. Clin Infect Dis, 2009. 48(5): p. 609-11.

4. Egger, M. and A. Boulle, Population effect of scaling up ART in resource-poor settings. Lancet, 2008. 371(9624): p. 1558-9. 
5. Reniers, G., et al., Mortality trends in the era of antiretroviral therapy: evidence from the Network for Analysing Longitudinal Population based HIV/AIDS data on Africa (ALPHA). AIDS, 2014. 28 Suppl 4: p. S533-42.

6. Egger, M., et al., Prognosis of HIV-1-infected patients starting highly active antiretroviral therapy: a collaborative analysis of prospective studies. Lancet, 2002. 360(9327): p. 119-29.

7. Kirchhoff, F. and G. Silvestri, Is Nef the elusive cause of HIV-associated hematopoietic dysfunction? J Clin Invest, 2008. 118(5): p. 1622-5.

8. Sullivan, P.S., et al., Epidemiology of anaemia in human immunodeficiency virus (HIV)-infected persons: results from the multistate adult and adolescent spectrum of HIV disease surveillance project. Blood, 1998. 91(1): p. 301-8.

9. Belperio, P.S. and D.C. Rhew, Prevalence and outcomes of anaemia in individuals with human immunodeficiency virus: a systematic review of the literature. Am J Med, 2004. 116 Suppl 7A: p. 27S-43S.

10. Jacobson, M.A., et al., Human immunodeficiency virus disease-related neutropenia and the risk of hospitalization for bacterial infection. Arch Intern Med, 1997. 157(16): p. 1825-31.

11. Scaradavou, A., HIV-related thrombocytopenia. Blood Rev, 2002. 16(1): p. 73-6.

12. Murphy, M.F., et al., Incidence and mechanism of neutropenia and thrombocytopenia in patients with human immunodeficiency virus infection. Br J Haematol, 1987. 66(3): p. 337-40.

13. Taremwa, I.M., et al., Prevalence of HIV-related thrombocytopenia among clients at Mbarara Regional Referral Hospital, Mbarara, southwestern Uganda. J Blood Med, 2015. 6: p. 109-13.

14. Dikshit, B., et al., Profile of hematological abnormalities of Indian HIV infected individuals. BMC Blood Disord, 2009. 9: p. 5.

15. WHO, Worldwide prevalence of anaemia 1993-2005. WHO Global Database on Anaemia Geneva 2008.

16. Gunda, D.W., S.B. Kilonzo, and B.C. Mpondo, Magnitude and correlates of moderate to severe anaemia among adult HIV patients receiving first line HAART in Northwestern Tanzania: a cross sectional clinic based study. Pan Afr Med J, 2016. 23: p. 26.

17. Meidani, M., et al., Prevalence, severity, and related factors of anaemia in HIV/AIDS patients. J Res Med Sci, 2012. 17(2): p. 138-42.

18. Williamson, D.R., et al., Thrombocytopenia in critically ill patients receiving thromboprophylaxis: frequency, risk factors, and outcomes. Chest, 2013. 144(4): p. 1207-15.

19. Sridhar, K.S., et al., Phase II trial of mitoxantrone in head and neck carcinoma. Am J Clin Oncol, 1991. 14(4): p. 298-304.

20. Mhozya, H., et al., Late-stage disease at presentation to an HIV clinic in eastern Tanzania: A retrospective cross-sectional study. Malawi Med J, 2015. 27(4): p. 125-7.

21. Nascimento, F.G. and P.Y. Tanaka, Thrombocytopenia in HIV-Infected Patients. Indian J Hematol Blood Transfus, 2012. 28(2): p. 109-11.

22. Ferede, G. and Y. Wondimeneh, Prevalence and related factors of anaemia in HAART-naive HIV positive patients at Gondar University Hospital, Northwest Ethiopia. BMC Hematol, 2013. 13(1): p. 8.

23. Kyeyune, R., et al., Prevalence and correlates of cytopenias in HIVinfected adults initiating highly active antiretroviral therapy in Uganda. BMC Infect Dis, 2014. 14: p. 496

24. Denue, B.A., et al., Prevalence of Anaemia and Immunological Markers in HIV-Infected Patients on Highly Active Antiretroviral Therapy in Northeastern Nigeria. Infect Dis (Auckl), 2013. 6: p. 25-33.

25. Johannessen, A., et al., Antiretroviral treatment reverses HIV-associated anaemia in rural Tanzania. BMC Infect Dis, 2011. 11: p. 190.

26. Deresse Daka, D.L.a.A.A., Prevalence of anaemia before and after the initiation of antiretroviral therapy at ART centre of Hawassa University Referral Hospital, Hawassa, South Ethiopia. Scholarly Journal of Medicine. , 2013. 3(1): p. 1-6.

27. Kaslow, R.A., et al., Infection with the human immunodeficiency virus: clinical manifestations and their relationship to immune deficiency. A report from the Multicentre AIDS Cohort Study. Ann Intern Med, 1987. 107(4): p. 474-80.
28. Enawgaw, B., et al., Determination of hematological and immunological parameters among HIV positive patients taking highly active antiretroviral treatment and treatment naive in the antiretroviral therapy clinic of Gondar University Hospital, Gondar, Northwest Ethiopia: a comparative cross-sectional study. BMC Hematol, 2014. 14(1): p. 8.

29. Akinsegun, Hematologic Abnormalities in Treatment-naive HIV patients. nfectious Diseases: Research and Treatment 12/2010; 3. , 2010. 2010(3): p. 45-49.

30. Jost, J., et al., [HIV-associated thrombocytopenia]. Schweiz Med Wochenschr, 1988. 118(6): p. 206-12.

31. Mocroft, A., et al., Anaemia is an independent predictive marker for clinical prognosis in HIV-infected patients from across Europe. EuroSIDA study group. AIDS, 1999. 13(8): p. 943-50.

32. O'Brien, M.E., et al., Anaemia is an independent predictor of mortality and immunologic progression of disease among women with HIV in Tanzania. J Acquir Immune Defic Syndr, 2005. 40(2): p. 219-25.

33. Odunukwe, N., Idigbe,O., Kanki, P., Adewole, T., Onwujekwe,D., Audu,R. and Onyewuche,J., Heamatological and Biochemical response to treatment of HIV-1 infection with a combination of nevirapine+stavudine+lamivudine in Lagos, Nigeria.". Turkish J. of Heamatol. , 2005. 22:(3): p. 7.

34. Harris, R.J., et al., Prognostic importance of anaemia in HIV type-1infected patients starting antiretroviral therapy: collaborative analysis of prospective cohort studies. Antivir Ther, 2008. 13(8): p. 959-67.

35. Omoregie, R., et al., Prevalence of anaemia among HIV-infected patients in Benin City, Nigeria. Tanzan J Health Res, 2009. 11(1): p. 1-4.

36. Opie, J., Haematological complications of HIV infection. S Afr Med J, 2012. 102(6): p. 465-8.

37. Moses, A., J. Nelson, and G.C. Bagby, Jr., The influence of human immunodeficiency virus-1 on hematopoiesis. Blood, 1998. 91(5): p. 147995.

38. Zon, L.I. and J.E. Groopman, Hematologic manifestations of the human immune deficiency virus (HIV). Semin Hematol, 1988. 25(3): p. 208-18.

39. Spivak, J.L., et al., Serum immunoreactive erythropoietin in HIVinfected patients. JAMA, 1989. 261(21): p. 3104-7.

40. Volberding, P.A., et al., Anaemia in HIV infection: clinical impact and evidence-based management strategies. Clin Infect Dis, 2004. 38(10): p. 1454-63.

41. Sipsas, N.V., et al., AIDS-related cutaneous Kaposi's sarcoma: failure of treatment with human chorionic gonadotropin. J Chemother, 1999. 11(1): p. 78-9.

42. Semba, R.D. and G.E. Gray, Pathogenesis of anaemia during human immunodeficiency virus infection. J Investig Med, 2001. 49(3): p. 225-39.

43. Kuller, L.H., et al., Inflammatory and coagulation biomarkers and mortality in patients with HIV infection. PLoS Med, 2008. 5(10): p. e203.

44. Tsiakalos, A., et al., Fine epitope specificity of anti-erythropoietin antibodies reveals molecular mimicry with HIV-1 p17 protein: a pathogenetic mechanism for HIV-1-related anaemia. J Infect Dis, 2011. 204(6): p. 902-11

45. Redig, A.J. and N. Berliner, Pathogenesis and clinical implications of HIV-related anaemia in 2013. Hematology Am Soc Hematol Educ Program, 2013. 2013: p. 377-81.

46. Rawat, R., S.I. McCoy, and S. Kadiyala, Poor diet quality is associated with low CD4 count and anaemia and predicts mortality among antiretroviral therapy-naive HIV-positive adults in Uganda. J Acquir Immune Defic Syndr, 2013. 62(2): p. 246-53.

47. Olayemi, E., O.A. Awodu, and G.N. Bazuaye, Autoimmune hemolytic anaemia in HIV-infected patients: a hospital based study. Ann Afr Med, 2008. 7(2): p. 72-6.

48. Trotter, J.F., Coagulation abnormalities in patients who have liver disease. Clin Liver Dis, 2006. 10(3): p. 665-78, x-xi.

49. Afdhal, N., et al., Thrombocytopenia associated with chronic liver disease. J Hepatol, 2008. 48(6): p. 1000-7.

50. Rios, R., et al., The role of thrombopoietin in the thrombocytopenia of patients with liver cirrhosis. Am J Gastroenterol, 2005. 100(6): p. 13116. 
51. Sheikh, M.Y., et al., Prevalence of cirrhosis in patients with thrombocytopenia who receive bone marrow biopsy. Saudi J Gastroenterol, 2012. 18(4): p. 257-62.

52. van den Bemt, P.M., R.H. Meyboom, and A.C. Egberts, Drug-induced immune thrombocytopenia. Drug Saf, 2004. 27(15): p. 1243-52.

53. Reese, J.A., et al., Identifying drugs that cause acute thrombocytopenia: an analysis using 3 distinct methods. Blood, 2010. 116(12): p. 2127-33.

54. Lee, K.H., K.P. Hui, and W.C. Tan, Thrombocytopenia in sepsis: a predictor of mortality in the intensive care unit. Singapore Med J, 1993. 34(3): p. 245-6.

55. Sloand, E.M., et al., Epidemiology of thrombocytopenia in HIV infection. Eur J Haematol, 1992. 48(3): p. 168-72.

56. Jokela, J., T. Flynn, and K. Henry, Thrombotic thrombocytopenic purpura in a human immunodeficiency virus (HIV)-seropositive homosexual man. Am J Hematol, 1987. 25(3): p. 341-3.

57. Gunther, K., D. Garizio, and P. Nesara, ADAMTS13 activity and the presence of acquired inhibitors in human immunodeficiency virus-related thrombotic thrombocytopenic purpura. Transfusion, 2007. 47(9): p. 17106.

58. Moore, R.D., Schistocytosis and a thrombotic microangiopathy-like syndrome in hospitalized HIV-infected patients. Am J Hematol, 1999. 60(2): p. 116-20.

59. Becker, S., et al., HIV-associated thrombotic microangiopathy in the era of highly active antiretroviral therapy: an observational study. Clin Infect Dis, 2004. 39 Suppl 5: p. S267-75.

60. Castella, A., et al., The bone marrow in AIDS. A histologic, hematologic, and microbiologic study. Am J Clin Pathol, 1985. 84(4): p. 425-32.
61. Moses, A.V., et al., Human immunodeficiency virus infection of bone marrow endothelium reduces induction of stromal hematopoietic growth factors. Blood, 1996. 87(3): p. 919-25.

62. Munshi, H.G. and R.B. Montgomery, Severe neutropenia: a diagnostic approach. West J Med, 2000. 172(4): p. 248-52.

63. Pluda, J.M., H. Mitsuya, and R. Yarchoan, Hematologic effects of AIDS therapies. Hematol Oncol Clin North Am, 1991. 5(2): p. 229-48.

64. Salmen, S., et al., Increased Fas-mediated apoptosis in polymorphonuclear cells from HIV-infected patients. Clin Exp Immunol, 2004. 137(1): p. 166-72.

65. Ahr, B., et al., Apoptosis of uninfected cells induced by HIV envelope glycoproteins. Retrovirology, 2004. 1: p. 12.

66. Nagu, T.J., et al., Anaemia at the initiation of tuberculosis therapy is associated with delayed sputum conversion among pulmonary tuberculosis patients in Dar-es-Salaam, Tanzania. PLoS One, 2014. 9(3): p. e91229.

67. Kerkhoff, A.D., et al., Predictive value of anaemia for tuberculosis in HIV-infected patients in Sub-Saharan Africa: an indication for routine microbiological investigation using new rapid assays. J Acquir Immune Defic Syndr, 2014. 66(1): p. 33-40.

68. Kilby, J.M., et al., The yield of bone marrow biopsy and culture compared with blood culture in the evaluation of HIV-infected patients for mycobacterial and fungal infections. Am J Med, 1998. 104(2): p. 123-8.

69. Khandekar, M.M., et al., Profile of bone marrow examination in HIV/ AIDS patients to detect opportunistic infections, especially tuberculosis. Indian J Pathol Microbiol, 2005. 48(1): p. 7-12. 